BODA ZSOLT

\title{
A környezetszociológia felé
}

\section{Szerzői információ:}

B $\quad$ B od a $Z$ solt

Közgazdász, tudományos főmunkatárs (MTA Politikatudományi Intézet).

$\mathbf{R}$

$\mathbf{M}$

Á

C

$\mathbf{I}$

Ó

$\mathbf{S}$

$\mathrm{T}$

Á

$\mathbf{R}$

$S$

A

D

Így hivatkozzon erre a cikkre:

Boda Zsolt. „A környezetszociológia felé”.

Információs Társadalom IV, 3-4. szám (2004): 80-87.

https://dx.doi.org/10.22503/inftars.IV.2004.3-4.12

A folyóiratban közölt müvek

a Creative Commons Nevezd meg! - Ne add el! - Így add tovább! 4.0

Nemzetközi Licenc feltételeinek megfelelően használhatók. 
B o d a Z solt

\section{A környezetszociológia felé}

Sükösd Miklós tanulmányához tizenegy hozzászólás érkezett - ez a tizenkettedik. A többsége igen kritikus: az írást úgyszólván darabokra szedik (Dányi Endre, Kiss Ulrich, Pintér Róbert, Z. Karvalics László), vagy totálisan elutasítják (Dessewffy Tibor, Hammer Ferenc). Mások viszont mintha totálisan elfogadnák (Lányi András, Pásztor János, Takács-Sánta András, Vay Márton). Ezt onnan gondolom, hogy ezek a hozzászólások Sükös Miklós írásáról nem sokat szólnak, különösen nem bírálóan - inkább az eredeti tanulmány állításait igyekeznek megvédeni a kritikusokkal szemben, vagy nem is szólnak másról, mint a kritikusok kritikájáról. Tudományos viták esetében merőben szokatlan az, hogy a hozzászólók ennyire egymással szemben álló táborokba tömörüljenek, a teljes elutasítás vagy a teljes elfogadás álláspontjára helyezkedve. Az ilyesmi inkább a politikai, az ideológiai vagy a hitviták sajátja.

Magam is úgy vélem, hogy Sükösd Miklós írása - végső soron - nem tudományos dolgozat, hanem gondolatgazdag esszé. Ugyanakkor értem és elfogadom az írást védelmezôk számos érvét is. Az alábbiakban ezért az „egyfelôl-másfelől” hintapolitikáját folytatva, az eddigi vita fényében igyekszem értelmezni az írást, és közben kifejtem saját álláspontomat is a témáról.

Az írás szabályos, a környezeti médiaszociológia tárgyában készült tudományos dolgozatnak indul (bár kétségtelen, hogy a múfaji meghatározás tekintetében már a mottók elbizonytalanítják az olvasót, hiszen afféle krédónak tûnnek, mintegy előlegezve a tanulmány üzenetét). Kijelöli a vizsgálat tárgyát, kategóriákat határoz meg, majd hipotézist fogalmaz meg. Néhány oldallal később azonban az olvasó idôközben erősödő gyanúja bizonyosságba fordul: az írás nem tanulmány, hanem számos érdekes és provokatív gondolatot megfogalmazó esszé, amelynek nyelvezete is egyre költôibbé, irodalmiassá válik, hogy aztán az utolsó oldalon egy apokaliptikus vízióban érje el a csúcspontját.

Következésképpen magam is jogosnak gondolom mindazokat a bíráló megjegyzéseket, amelyek a tudományosságot kérik számon az íráson. Ezt a várakozást ugyanis bevezetőjével éppen a dolgozat kelti a gyanútlan olvasóban. Nem sorolom föl a hozzászólásokban megfogalmazott összes olyan kritikát, amellyel egyetértek. Néhány mozzanatra még visszatérek, most csak címszavakban: az írás nem tisztázza azokat a (média)elméleti alapokat, amelyekre épít; differenciálatlanul használja a kategóriákat (például „a” média fogalmát); egyoldalú és elfogult képet mutat „„” média szerepéről a környezeti problematikában; nem szól a közönségról, a befogadás módjairól, illetve egysíkúan a manipulálható, „agymosott” médiafogyasztó képét sugallja; vitatható állításait nem támasztja alá sem elméleti érvekkel, sem empirikus adatokkal.

Mondani sem kell, hogy az elméleti alapok, a kategóriák vagy a hipotézisek kifejtésének hiánya nem fogható a szúkös keretekre. Mindezek bemutatása röviden is elintézhetô, utalva a releváns szociológiai elméletekre, a szakirodalomra - ha pedig ezek hiányoznak, akkor nyilvánvalóvá kellett volna tenni, hogy a szerzố mely pontokon él feltevésekkel. Nem kell továbbá pozitivistának, de még popperistának sem lenni ahhoz, hogy efféléket elvárjunk egy önmagát tudományos tanulmánynak defini- 
áló írástól. Polányi Mihály szerint (aki pedig sokat tett a tudomány objektivista mítoszának lerombolásáért) a tudomány egy „tiszteletre méltó hagyomány”, amelynek legitim eljárásai vannak. Ennek fényében nincs igaza Lányi Andrásnak, amikor azt írja, hogy „sosem tudunk eleget”, és az igazság nem a számok összeadásán múlik. Kicsit egyszerûsítve (hiszen vannak kvalitatív kutatási módszerek stb.): a tudományos igazság igenis a számok összeadásán, de legalábbis a tudomány normáinak és eljárásainak követésén múlik, merô procedurális logika alapján. Ettől még nem lesz persze magasabbrendû mondjuk a mûvészet vagy a vallás igazságánál. Szívesen egyetértek továbbá azzal is, hogy a legfontosabb dolgokról a tudomány nyelvén nem tudunk szólni de akkor ne is akarjunk úgy csinálni, mintha.

Az írást elutasító kritikusok azonban meglátásom szerint túl messzire mentek, és a szerzőnek már olyan megállapításait is megkérdőjelezték, elvetették, amelyek pedig védhetőek. Továbbá Sükösd Miklós számos olyan állítást tesz, amelyeken legalábbis érdemes elgondolkodni, és bár hiányzik mögülük az elméleti vagy empirikus alátámasztás, egy empatikus olvasatban legalább hipotéziseknek azért tekinthetôk. Lássuk ezek a közül a legfontosabbakat!

A kritikusok (elsôsorban Dessewffy Tibor, Hammer Ferenc és Kiss Ulrich) mind szükségét érezték, hogy Sükösd Miklós dolgozatának axiomatikus kiindulópontját is relativizálják: azt, hogy van ökológiai krízis, amelyért elsősorban a modern társadalmak a felelősek. Az ezzel kapcsolatos ostoba és arrogáns megjegyzéseik joggal vál tották ki a „környezetvédôk” felháborodását. A globális ökológiai krízis ugyanis tudományos ténynek tekinthetô, abban az értelemben, ahogyan a természettudományokban beszélhetünk tényekről (a „tiszteletreméltó hagyományokra” támaszkodó eljárások alapján stb...). Az ENSZ égisze alatt múködő Kormányközi Éghajlatváltozási Bizottság például a világ vezetố klímakutatóiból áll, és lassan húsz éve vizsgálja a klímaváltozás lehetőségét és benne az ember szerepét. Az egymást követő jelentéseik egyre nagyobb bizonyossággal állítják, hogy 1.) a légkörben az utóbbi két évszázadban feldúsultak az üvegház hatású gázok, és ez a földi átlaghőmérséklet 0,3-0,6 Celsius fokos emelkedését okozta az elmúlt száz évben, valamint előreláthatóan 2-3 fokos emelkedést fog okozni a XXI. század folyamán; 2.) e jelenség mögött az emberi tevékenység áll. A becslések szerint a fosszilis energiahordozók (szén, olaj, gáz) elégetésével az emberiség az ipari forradalom óta több szén-dioxidot juttatott a levegóbe, mint az azt megelốzố tízezer évben (!). A mezőgazdasági mûvelés a talajban kötött szén-dioxidot szabadította fel, valamint csökkentette a szénmegkötő erdők kiterjedését. Mindezek miatt a légköri szén-dioxid koncentráció ma mintegy $33 \%$-kal magasabb az ipari forradalmat megelốzố idôszakhoz képest. Ugyanígy részletes vizsgálatok bizonyítják a fajpusztulás drámai mértékét, az ózonréteg elvékonyodását, a talaj és a vizek fokozódó kémiai szennyezôdését, a globálisan rendelkezésre álló ivóvíz mennyiségének csökkenését. ${ }^{1}$

\footnotetext{
${ }^{1}$ Magyarul is számos olyan kiváló mú áll rendelkezésre a globális ökológiai válságról, amelyekből tájékozódni lehet: például Carson (Carson, 1995), Darvas (Darvas, 2000), Ehrlich (Ehrlich, 1995), Faragó (Faragó, 1993), Faragó - Kerényi (Faragó - Kerényi, 2003), Pálvölgyi (Pálvölgyi, 2000), Rakonczai (Rakonczai, 2003), Vida (Vida, 2001), Wackernagel - Rees (Wackernagel - Rees, 2001), valamint "A világ helyezete" címû, évente megjelenố kiadvány.
} 
Sok persze a bizonytalanság, hiszen az ökológiai rendszerek komplexitása hatalmas. Nem tudjuk például bizonyosan, hogy az éghajlatváltozásnak milyen hatásai lesznek: a tengerszint-emelkedés (nem elsősorban a jéghegyek elolvadása, hanem a tengerek hôtágulása miatt) ugyan bizonyosnak látszik, ám például a Golf-áramlat leállása (és így Európa északi felének eljegesedése) csak modellekre alapozott feltevés. A Sükösd Miklós által is axiómának elfogadott állítás igaza felől azonban nincs kétség: az ember globális méretekben és drámai sebességgel alakítja át a környezetét. Ezt az átalakítást nemcsak azért nevezhetjük pusztításnak, mert fajok millióinak az eltûnésével jár, hanem azért is, mert az emberre nézve is pusztítóak a következményei. (Egy jó kis fajpusztítás, kedves Dessewffy Tibor, nemcsak azért nem jár az emberiségnek, mert a többi élôlénnyel szemben morálisan helytelen, hanem elsôsorban azért, mert saját életlehetôségeinket tesszük tönkre általa. A biodiverzitás ugyanis nemcsak a szafari-turisták által fényképezett afrikai nagyvadakat jelenti, hanem azon ökoszisztémákat és a bennük élő baktériumokat, gombákat, algákat is, amelyek az alapvetô „ökoszisztéma-szolgáltatásokat”, így az élố talajt vagy a levegốt számunkra előállítják.) Nincs tehát igaza Kiss Ulrichnak, amikor Sükösd Miklós írásán számon kéri az ökológiai krízis tényének igazolását. Speciel itt nem hiányzott semmilyen igazolás.

Ugyancsak nem szorul hosszasabb tárgyalásra az, amit Sükösd - helyesen - egy bekezdésben elintézett: hogy tudniillik a globális ökológiai krízisért elsôsorban a fejlett országok társadalma a felelős. Bizony, kedves Hammer Ferenc, pontosan a médiafogyasztó városi középosztály pusztítja leginkább a környezetet: szobájában energiafaló légkondicionáló és még számos elektromos eszköz található, garázsában benzinégetô autócsoda, hưtôjében a sokezer kilométert utaztatott déligyümölcs. Neki dolgoznak az erőművek, a gyilkos permetezőszereket használó intenzív mezőgazdaság, a vegyipar, a műanyagipar, az olajipar, az ô kedvéért épülnek az autópályák... Minden számítás azt mutatja, hogy a világ lakosságának leggazdagabb 20 százaléka fogyasztja el az erôforrások mintegy 75 százalékát: például a világnépesség 5 százalékával rendelkező Egyesült Államok felelős a klímaváltozást okozó gázok kibocsátásának 20 százalékáért.

Természetesen az ember mindig is nagy találékonysággal alakította át maga körül a természeti környezetet, mint erre Z. Karvalics László is utal. Csak azt nem tudom, ez az érv miért nyugtat meg bárkit is. Az a tény, hogy őseink kezdetleges eszközökkel és néhány kecskenyájjal is képesek voltak pusztasággá változtatni korábban virágzó vidékeket (lásd a Termékeny Félhold történetét), inkább el kellene, hogy borzasszon minket: hiszen akkor vajon mire vagyunk képesek most, vegyiparral, sokmillió autóval, atomerômûvekkel - és bombákkal?! Bizony, míg korábban elsôsorban fizikailag és viszonylag lokálisan tettünk tönkre ökoszisztémákat, most a fizikai pusztítás mellett a vegyi, a biológiai (lásd géntechnológia) és a sugárszennyezési módszerek gazdag arzenálját vetjük be a Földanya ellen, a mélytengerektől a sztratoszféráig otthagyva kézjegyünket.

Ebben az értelemben a modernitáskritika teljesen helyénvaló. Szerethetjük a modernitást kilencvenkilenc okból (én majdnem ennyi okból szeretem is), van azonban legalább egy, ami miatt elfogadhatatlan (és ez abszolút belső kritika): egyelốre nagyon úgy néz ki, hogy önpusztító. Mivel azonban a modern társadalom környezetpusztítása már globális kiterjedésû, sốt, maga a modern társadalom is lassan világméretû, hiszen ez az uralkodó fejlődési irány, amelyet majd' minden ország elfogad, félő, hogy pusztulása nem „csak” egy társadalom, hanem - fogalmazzunk egyszerüen a világ katasztrófája lesz. 
Teljesen legitim kutatási irány tehát, ha a társadalomtudósok górcsố alá veszik a modern társadalom és gazdaság intézményrendszerét, azt vizsgálva, hogy azok miként járulnak hozzá a modern társadalmak ökológiailag destruktív, és fenntarthatatlan (értsd: az ember életlehetôségeit és életminőségét fenyegetô, mert persze valahányan biztosan el tudnak vegetálni egy eljegesedett Európában is, betonbunkerekben, gázmaszkban) múködéséhez. Az ökológiai közgazdaságtan például a gazdaság elméletét és gyakorlatát vizsgálja ilyen szempontból (vö. Pataki - Takács-Sánta, 2004). Milyen hallgatólagos vagy kifejezett értékek és milyen, a valóságra vonatkozó előfeltevések vezetik a modern közgazdaságtan? Milyen intézményi logikák határozzák meg a piacgazdaság múködését? Milyen más típusú modelleket és gazdasági gyakorlatokat találhatunk, amelyek képesek integrálni a környezet megóvásának szempontjait is? És így tovább.

Mármost Hannigan (Hannigan, 1995) szerint a környezeti szociológiának két alapvető kutatási iránya van. Az egyik a környezetkárosítás társadalmi okait vizsgálja. A másik azt, hogy miként jön létre és hogyan alakul a környezeti diskurzus, a környezetvédelmi tudatosság; mi ebben a tudománynak, a médiának vagy az új társadalmi mozgalmaknak a szerepe. (Én egy harmadikat is hozzátennék, amelyet szépen példáz Homer-Dixon magyarul idén megjelent könyve: A környezet károsodása milyen - elsősorban negatív - hatással van a társadalmi intézmények hatékony múködésére?) Hannigan a saját megközelítését konstruktivistának vallja, és akárcsak a környezetszociológusok többségét, ôt is elsősorban a másodikként említett téma érdekli, vagyis hogy miként jön létre a környezetrôl való társadalmi tudás. Ugyanakkor leszögezi - és én mélyen egyetértek vele -, hogy a konstruktivizmusnak nem kell totális relativizmushoz vezetnie a környezeti problémák mibenlétét illetően. A környezetrôl - mint bármi másról - való tudásunk persze társadalmi konstrukció, és valóban izgalmas azt tanulmányozni, hogy ez a konstrukció milyen tényezók hatására változik; melyek a meghatározó témacsomópontjai; melyek az uralkodó metaforái; és így tovább. Jó okunk van azonban azt gondolni, hogy már tudunk annyit az ökológiai krízisrôl, hogy létét elfogadjuk, és így persze az elsőként említett problémakör vizsgálata is teljesen legitim. Egy ilyen vizsgálódást szükségképpen nem kizárólag a tiszta megismerôi érdek vezérli (ha van ilyen), azaz normatív elemeket is fog tartalmazni. Mivel abból indul ki, hogy elismerten valami baj van a társadalmunkkal, arra törekszik, hogy e baj gyökereit azonosítsa, és adott esetben ajánlásokkal éljen a terápiát illetően is. Ugye nem kell érvelnem amellett, hogy a normatív mozzanat korántsem idegen a társadalomtudományoktól? A modern közgazdaságtan például abból indul ki, hogy az emberek számára a gazdasági jólét növekedése fontos, így egész elméleti konstrukciója és gyakorlati ajánlásai e cél előmozdítására irányulnak.

Sükösd Miklós írása, nekem úgy tűnik, szándéka szerint egy olyan környezetszociológiai tanulmány akart volna lenni, amely azt vizsgálja, hogy egy bizonyos társadalmi intézmény (a média) miként járul hozzá a környezetpusztító modern társadalom múködéséhez. Mint kiindulópont ez teljesen védhető. Személy szerint intuitíve elfogadom az írás számos megállapítását is: egyetértek azzal, hogy a kereskedelmi média napirendje, uralkodó narratívái, a fogyasztói társadalom értékrendjének és viselkedési mintázatainak mint hegemón (azaz legitim módon nehezen megkérdôjelezhetô - vö. Gramsci) diskurzusnak a bemutatása valóban nem a „zöld” megközelítésnek kedveznek. Számos más megállapítást ugyan vitathatónak, de mindenképp további 
vizsgálatra méltónak gondolok. Érdekes lenne például megvizsgálni, hogy a globális média (és globális tartalmai) vajon milyen típusú attitűdöket erősítenek inkább: a „kicsi, véges, sebezhető világ” érzését, vagy valóban a „bárhol ott lehetsz, bárhonnan elmehetsz, sehova sem tartozol" kontingenciáját. Egy másik nagy kérdés a médiakörnyezet és a valóságos környezet szembeállítása, amelyet minden médiaszociológus hozzászóló hevesen vitatott. Személy szerint bonyolultabbnak gondolom ezt a problémát annál, hogysem kézfeltartással helyben eldönthetnénk. Jó pszichológiai érvek szólnak ugyanis amellett, hogy a különbözố tapasztalási módok nem egyformák vagy egyenértékúek. Ha ez az egyén esetében így van, akkor - bár nem szeretnék a módszertani individualizmus hibájába esni - legalábbis elgondolkodtató, hogy a kollektív tudatot ez miképp befolyásolja. (Miért van az, hogy az Interneten kötött kapcsolatok nem olyan tartósak, mint a „valóságosak"? Van egy fogadásom, hogy ezen az sem fog segíteni, ha „real time” kép- és hangkommunikáció zajlik az ismerkedő felek között.)

Túl azonban azon a már jelzett problémán, hogy az állítások nincsenek megfelelően igazolva a tudomány diskurzusával, az egész tanulmányban látok még egy komoly hiányosságot. Tudniillik azt, hogy Sükösd Miklós eljárásával szemben a média nem tekinthető csupán olyan társadalmi intézménynek, amely a fennálló rendet stabilizálja, mûködteti. Az ökológiai közgazdász megteheti, hogy csak azt vizsgálja, miként és mennyire nem fenntartható a gazdaság. A környezeti médiaszociológus azonban nem teheti meg, hogy csak a Hannigan által elsôként említett problémakörrel foglalkozik, ugyanis a média (a tudomány és az oktatás mellett) az egyik legfontosabb mező, amelyen a társadalmi tudás termelése és elosztása zajlik. Ha van valamennyi környezeti tudatosság, akkor létrejöttében vizsgálni kell a média szerepét is.

Rémisztô, ugyanakkor elképesztôen izgalmas folyamatnak vagyunk szemlélôi és résztvevôi: az ökológiai szempontból ön- és közveszélyes modern társadalom próbál szembenézni saját ön- és közveszélyes mivoltával. Abban Hammer Ferencnek nincs igaza, hogy ez valami gyökeresen új dolog lenne: a történelem folyamán számtalan emberi közösség került abba a helyzetbe, hogy alkalmazkodnia kellett az általa drámaian átalakított természeti környezet feltételeihez. Jónéhány közösségnek, társadalomnak ez sikerült, bár néha azon az áron, hogy szigorú környezethasználati vagy családpolitikai szabályokat kellett bevezetnie, esetleg gyökeresen át kellett alakítania szokás- és értékrendszerét (néhány példa in: McDaniel-Gowdy, 2002). A környezeti tudatosság mostani kialakulása persze annyiban más, hogy a korábbiakhoz képest öszszehasonlíthatatlanul komplexebb, és így fenntarthatatlanságában is komplexebb társadalomban megy végbe. A legkevesebb, ami állítható, hogy ez a kihívás mennyiségében, vagyis „kilóra” nagyságrendekkel múl felül minden korábbit. Izgalmas kérdés tehát, hogy ha ez az önreflexív folyamat tovább megy (elindulni ugyan elindult, de még leállhat), akkor az milyen intézmények átalakulásával fog járni. Mennyire marad a modern társadalom önmaga, és mennyire változik meg, ha fenntarthatóvá válik? Mennyire képes hasznosítani saját vívmányait (tudomány, technika, piac - és média), és mennyiben fog teljesen más intézményeket, mûködési módokat, értékeket és érzékenységeket kifejleszteni? 
Van tehát dolga a környezetszociológusnak. Annak is, amelyik a médiával foglalkozik. Úgy vélem azonban, hogy nem akkor jár el helyesen, ha a médiát egyoldalúan csak mint a rendszert stabilizáló, hegemón logikát megtestesítő intézményt ábrázolja. Minden hétköznapi tapasztalatunk azt sugallja, hogy az ökológiai krízisrôl igenis van kollektív tudás, zajlik valamiféle közbeszéd, sốt, ez a diszkurzív folyam (na jó: patak) szélesedik is. Ha Sükösd Miklósnak igaza lenne, és a média kizárólag „antiökologikus" tartalmakat közvetítene, és a hatása abban merülne ki, hogy stabilizálja a világunkat felélő fogyasztói kultúra értékeit és viselkedésmintázatait, akkor a helyzet még a mainál is sokkal rosszabb lenne! A tények ugyanis mást is mondanak: például az emberek többsége minden felmérés szerint tud a környezeti problémákról, aggasztja őket, a legfontosabb problémák közé sorolják stb. Ami meglepő, hogy persze országonként vannak különbségek, de azért ez világszerte így van, nemcsak Skandináviában, hanem Argentínában, és Indonéziában is (Dunlap et al., 1993). A kilencvenes évek a nyugati világban a zöldmozgalom felfutását hozták minden mérce szerint: értékszociológiai vizsgálatok a posztmodern értékek megerősödését, valamint a környezetvédôkbe vetett bizalom növekedését mutatják (Inglehart, 1997), a zöld szervezeteknek kibővült a tagsága, megnốtt a számukra juttatott adományok összege, s így a Greenpeace és a WWF költségvetése is megsokszorozódott.

Magyarországon a felmérések hasonló eredményeket mutatnak. Az emberek az ökológiai krízist az egyik legfontosabb világproblémának tartják (Székely, 2003). A budapestiek szerint a környezet állapota az öt legfontosabb probléma között van, a magyar fiatalok szerint a második legfontosabb probléma (megelőzve a gazdaság állapotát), a 35 év alatti internetezô nôk az öt legfontosabb téma között említik stb. stb. Hogyan lehetséges mindez? Világunk alapvetôen nem fenntartható, ráadásul napi sokórányi médiafogyasztásból is egy konzumerista ideológia ömlik ránk - ehhez képest (legalábbis az attitûdök és az ismeretek szintjén) az emberek sokkal „zöldebbek”, mint amilyennek lenniük kellene. (Lehet, hogy még így sem elég zöldek, de ez más kérdés, no meg bonyolultabb is.) Az általános zöldülés ráadásul a kilencvenes években zajlott le, amikor pedig a kereskedelmi média robbanása is megtörtént szerte a világban, nemcsak Magyarországon - ez pedig Sükösd Miklós feltevését a kereskedelemi média és a környezetrombolás ok-okozati kapcsolatáról legalábbis meggyengíti.

Van-e meggyőző elméletünk a média társadalmi szerepéről ma, amikor „a” média nagyon sok mindent jelent, írott sajtót, százféle tévéadót, na és az Internetet a maga „bázisdemokratikusabb” kommunikációs módozataival? Tudjuk-e, hogyan folyik a médiatartalmak befogadása? Valóban csak egyoldalú manipuláció és passzív befogadás lenne az egész? Biztos, hogy a befogadás bonyolultabban megy, mintsem hogy direkt módon indoktrinálna minket „a” média - benne vagyunk mi is aktívan, valamint az a közösség, amellyel értelmezzük, feldolgozzuk az élményeket. Lehet például, hogy a Népszabadság rövid híre a Pentagon éghajlatváltozási vészforgatókönyveirôl sokkal fontosabb, mint 10-20 órányi ValóVilág, reklám, és szappanopera. Talán ott inkább van az az érzésünk, hogy a „valóság” bejelentkezett, míg az utóbbiak sokórányi médiakábulata ugyan befolyásol, persze, de mégis, valahol tudjuk, hogy ez nem igazi. Mindezen hatásokról nem tudunk semmit.

A média továbbá lehetôvé teszi a globális szolidaritás létrejöttét, és megint: vannak evidenciák, amelyek azt mutatják, hogy ezt a lehetôséget valamelyest be is teljesítette. James Rosenau szerint a mai nemzetközi kapcsolatokat többek között az vál- 
toztatta meg, hogy megsokasodtak a „fejlett analitikus készséggekel és érzelmi kompetenciával rendelkezố egyének", akik képesek a komplex vagy a térben távoli eseményekról is megfelelő információt szerezni (pl. az Interneten keresztül), és ezekrôl politikai-morális állásfoglalást kialakítani. A világpolitika is megváltozott tehát, és részben a média miatt, amely közel hozza a távoli eseményeket. A globális problémák (ózonritkulás, éghajlatváltozás, fajok kihalása), vagy akár a regionálisak (savas esők okozta erdôpusztulás a szomszéd országban) érzékeléséhez, megértéséhez pedig nem az kell-e éppen, hogy tudjunk arról, máshol mi történik? Ezeket a problémákat lokálisan nehéz érzékelni, felfogni, ehhez más kell: hogy lássuk a szemgyulladásos, vak chilei birkákat, az erdejükból elüldözött amazonasi indiánokat (vö. Sting akciója), a leöldökölt bálnákat. Tény, nem ezek uralják a tabloid médiát, de azért csak előfordulnak benne. És egy ilyen drámai kép nem nyom-e többet a latban, mint sokórányi tabloid Spektrum és Walt Disney giccs?

Ha a befogadás útjai tényleg kanyargósabbak, mint gondoljuk, az persze megnehezíti a médiaszociológus helyzetét is. Hiszen a média és a környezet problémáját nem szükségképpen világítja meg egy egyszerú tartalomelemzés: lehet, hogy a környezetvédelmi témák részaránya éppen csökkent a médiában, de mivel már más a befogadó közeg, és mondjuk nem kisnézettségû értelmiségi músorokban, hanem az átlagnézőt mellbeverô Fókusz-riportokban van az a kevés, ami van, így is jobban hat, mint korábban.

Ezek a gondolatok semmiképpen sem kívánják azt sugallni, hogy a média „környezetbarát" lenne, és a lehető legjobban végezné a dolgát a fenntartható társadalom elổmozdításában. Nem kell tudósnak lenni ahhoz, hogy tudjuk: ez természetesen nincs így. Csupán arra kívántam rámutatni, hogy a tények sokfélék, és ha meg akarjuk érteni a környezeti diskurzus dinamikáját, akkor differenciáltabban érdemes szemügyre venni és vizsgálni a média szerepét is - hiszen ez az egyik legfontosabb tere a környezeti diskurzusnak is.

Azt sem gondolom, hogy a környezettudatosságnak az a növekedése, ami az elmúlt két évtizedben világszerte lezajlott, elegendő lenne. Természetesen nem elég, hiszen a társadalom, amelyben élünk, továbbra is fenntarthatatlan módon múködik. De lehet, hogy nem pusztán mennyiségi kérdésről van szó, mint ahogy azt elôzô mondatom is sugallhatta. Sok mindenen múlik, hogy mitôl változik meg az ember viselkedése vagy a társadalom működése. Meglehet, korunk a par excellence skizofrén kor, amelyben minden nehézség nélkül kerülnek agyunkban egymás mellé kognitíve nehezen összeegyeztethető tudattartalmak, és mi vígan együtt tudunk élni ezzel a kognitív disszonanciával. De az is biztos, hogy a cselekvés csak részben függ a tudatosságtól és az értékektôl. A környezettudatos cselekvéshez már más, társadalmi, strukturális, infrastrukturális stb. lehetőségek, mưködőképes, elérhető és megfizethető alternatívák is kellenek. A környezetszociológusnak tehát mindenképp túl kell lépnie a média vizsgálatán, ha arra kíváncsi, melyek az ökológiailag fenntarthatatlan társadalmi múködés okai, és hogyan változtathatók ezek meg. 


\section{IRODALOM}

Carson, Rachel (1995): Néma tavass. Budapest, Katalizátor Iroda

Darvas Béla (2000): Virágot Oikosnak. Kísértések kémiai és genetikai biatonságunk ürügyén. Budapest, L'Harmattan

Dunlap, R.E. - G.H. Gallup, Jr. - A.M. Gallup (1993): „Of Global Concern: Results of the Health of the Planet Survey", Environment, 35(9), pp. 7-15.

Ehrlich, Paul - Ehrlich, Anne (1995): A fajok kihalása. Budapest, Göncöl

Farag6 Tibor (1993): „Közös üvegházunk”, Környezet és Fejlödés, III/6-7, pp. 41-46.

Farago Tibor - Kerényi Attila (2003): Nemzetközi együttmüködés az éghajlatváltozás veszélyének, az üvegházhatású gázok kibocsátásának csökkentésére. (KvVM, Budapest)

Hannigan, John A. (1995): Environmental Sociology: A Social Constructionist Perspective. London, Routledge

Homer-Dixon, T. F. (2004): Környezet, szükösség, erốszak. Budapest, Typotex Kiadó

Ingelhart, Ronald (1997): Modernization and Postmodernization. Cultural, Economic, and Political Changes in 43 Societies. Princeton, Princeton University Press

McDaniel, Carl N. - John M. Gowdy (2002): Az édenkert kiárusitása. Példázat a természet tönkretételéröl. Budapest, Typotex Kiadó

Pálvölgyi Tamás (2000): Az új évezred környezeti kihívása: az éghajlatváltozás. Budapest, LHarmattan

Pataki György - Takács Sánta András, szerk. (2004): Természet és gazdaság. Ökológiai közgazdaságtan szöveggyüjtemény. Budapest, Typotex

Princen, Thomas - Matthias Finger (1994): Environmental NGOs in World Politics. Linking the Global and the Local. London, Routledge

Rakonczai János (2003): Globális ökológiai problémák. Szeged, Lazi Könyvkiadó

Rosenau, J. N. (1997): Along the Domestic-Foreign Frontier. Exploring Governance in a Turbulent World. Cambridge, Cambridge University Press

Székely Mozes (2003): Világproblémák világképiunkben, PhD értekezés, ELTE BTK Pszichológia Doktori Iskola

Vida Gábor (2001): Helyünk a bioszférában. Budapest, Typotext

Wackernagel, Mathis - William E. Rees (2001): Ökológiai lábnyomunk. Hogyan mérsékeljük as ember hatását a földön? Budapest, Föld Napja Alapítvány 